\title{
BERKARYA MUSIK: ANTARA HARAPAN DAN TANTANGAN
}

\section{Warsana $^{1}$}

\begin{abstract}
Abastract
It is not easy to create musical works. It requires perseverance, toughness, broad knowledge and experience in addition to long creative process for musicians to pour their ideas into musical works that are intelligible and enjoyable. Different artists have different understanding of artistic works with certain theme and they have their own way to interpret the artistic works. There are various challenges they artists must face in creating good artistic works that are enjoyable by their audience or music lovers. The creative process is carried out by exploring, observing, improvising and arranging the results of the exploration, the observation and the improvisation in a good composition. It is the key for the artists to the success in their artistic creation.
\end{abstract}

Keywords: Music, Creativity, Performance

\section{Pendahuluan}

Seni lahir sebagai pemenuhan keinginan bawah sadar. Karya seni adalah perwujudan terselubung dari keinginan tersebut. ${ }^{2}$ Karya seni adalah sebuah entitas yang dikerjakan atau dibuat melalui proses kesadaran kreatifitas yang berorientasi pada nilai dan pencapaian tujuan estetis. Karya seni dianggap mempunyai nilai kejiwaan, artinya karya seni kehadirannya terkait pada makna atau isi hati dari penciptanya sehingga apa yang dirasakan si pencipta dapat menggugah jiwa atau perasaan orang lain menjadi sama. Sebuah karya seni dibuat atau diciptakan semata-mata bukan sekedar untuk ditampilkan, dilihat dan didengar saja. Karya seni diciptakan penuh dengan gagasan, pendirian, pertimbangan, hasrat, kepercayaan, serta pengalaman tertentu yang hendak dikomunikasikan penciptanya. Suatu ide atau gagasan tertentu dapat merupakan "pesan" (messege) yang ingin dikomunikasikan oleh si senimannya kepada penikmat seni untuk mendapatkan respon sebagai " feedback" atas kehadiran karya seninya yang sekaligus juga menerima pesan/ informasi yang disampaikan. ${ }^{3}$

\footnotetext{
${ }^{1}$ Dosen Jurusan Etnomusikologi Fakultas Seni Pertunjukan Institut Seni Indonesia Yogyakarta. ${ }^{2}$ Nooryan Bahari, Kritik Seni Wacana Apresiasi dan Kreasi, Yogyakarta: Pustaka Pelajar, 2008, 65. ${ }^{3}$ Soeprapto Soejono, “Dialektika Seni: Proses Komunikasi “ Informasi dan Tanggapan” Estetis” dalam Y. Sumandiyo Hadi, ed.al, Rinengganing: Pak Bandem Yang Ngebyar, Yogyakarta: ISI Yogyakarta, 2006, 126.
} 
Seni mengekspresikan sisi-sisi emosional atau subjektif dari kepribadian manusia, dan karena itu dibedakan dengan ilmu pengetahuan melalui dominasi subjektivitas atas objektivitas. Seorang seniman akan berbeda ketika mengimajinasikan sesuatu dengan seorang ilmuwan. Seorang ilmuwan dalam imajinasinya barang kali tidak mempunyai pengaruh apapun atas hasil observasinya secara langsung, akan tetapi bagi seorang seniman justru imajinasi atau pribadinya hidup dan bergejolak secara spontan. Menjelma ke mana-mana seakan-akan segala sesuatu yang diekspresikannya itu dimasukkan ke dalam lautan imajinasi dan pribadinya sehingga orang menganggap bahwa seniman hidup dengan emosi dan subjektivitasnya.

Karya seni lahir dari keinginan pencipta yang terselubung dari rasa dan luapan emosi dalam dirinya. Keinginan itu ia curahkan ke dalam sebuah karya baik musik, lukis, tari, teater atau sebagainya, tergantung dari latar belakang kehidupan si pencipta itu sendiri. Kalau ia seorang yang berlatar belakang pelukis maka ia dapat mencurahkan ide atau gagasan-gagasannya ke dalam lukisan. Sedangkan kalau dia seorang penari maka ia dapat mencurahkan ide dan gagasan gerak-geraknya ke dalam karya yang berujud tarian. Begitu pula adanya apabila ia berlatar belakang pemusik maka ide dan gagasannya dapat ia curahkan ke dalam karya musik.

Karya seni yang baik tidak serta merta atau muncul secara tiba-tiba atau manifestasi sembarangan. Penciptaan karya seni membutuhkan pemikiran dan perenungan yang matang serta adanya dorongan yang kuat dari berbagai aspek. Pada saat ide atau gagasan muncul dan hendak diwujudkan dalam sebuah karya seni, seorang seniman tentunya mulai mempertimbangkan bahan dan hal apa saja yang dapat mewujudkan ide atau gagasan tersebut. Ungkapan perasaan atau ekspresi diri dapat terlihat dari karya yang ia paparkan, karena sebuah karya adalah perwakilan atau perwujudan dari si seniman itu sendiri. Ekspresi yang ada dalam karya seni diharapkan dapat dimengerti oleh penikmatnya, artinya makna yang terkandung dalam karya itu mampu menembus dinding pemikir terhadap masyarakat sebagai pemerhati.

Ketajaman pola pikir dan pengalaman atau intuisi baik seniman sebagai pembuat karya dan masyarakat sebagai pemerhati seni diperlukan satu pemahaman yang sama. Ketika benang merah antara kehendak seniman dengan masyarakat sebagai pemerhati seni dapat mengerti dan memahami apa yang dimaksudkan bagai sebuah rangkaian yang tak terputus, maka dengan demikian tidak serta merta hal itu sebagai sebuah 
pembenaran. Sebagai contoh kita sering menjumpai dalam suatu masyarakat tertentu dapat mengerti dan menerima terhadap sebuah karya yang dianggap kontroversi, di sisi lain masyarakat tidak mau tahu dan menolak hadirnya karya tersebut.

Barangkali adalah suatu kebiasaan atau memang orang tidak bisa dipaksakan untuk memilih satu di antara sekian pilihan. Kita dapat melihat fenomena musik yang belakangan ini muncul dengan beragam style dari yang tradisi, pop, dangdut, campursari sampai kontemporer. Semua disuguhkan berdasar selera masyarakat sebagai penikmat. Dengan kata lain kita harus mengerti tentang selera masyarakat yang dikehendaki sebagai penanggap seni. Keduanya bertolak pada pengalaman masing-masing. Seseorang yang kaya akan pengalaman seni dan pengetahuan seni akan lebih mampu mengembangkan, memperkaya, dan memberikan kedalaman pengalaman seninya. ${ }^{4}$

Memahami akan karya musik janganlah dipandang hanya satu sisi arti yang sempit yakni keindahan, akan tetapi harus dimaknai dari sudut pandang yang lain. Keindahan tidak menjadi syarat mutlak bagi lahirnya sebuah karya seni, sebaliknya, yang disyaratkan adalah motivasi penciptanya. Seni adalah segala sesuatu yang dibuat orang bukan karena didorong oleh keinginan untuk memenuhi kebutuhan pokok, melainkan adalah karena desakan kebutuhan sekunder, yaitu kebutuhan akan kemewahan, kenikmatan, atau kebutuhan spiritual. Seni dipandang sebagai ungkapan perasaan dan bentuk ekspresi yang keluar dari diri seniman. Sehingga apa yang ada dalam diri seniman baik itu suasana hati, perasaan atau apapun ungkapannya akan terwakili dari sebuah karya. Thomas Munro, seorang filsuf dan teoris seni, menyatakan bahwa baginya seni adalah alat buatan manusia yang dibuat untuk menimbulkan efekefek psikologis atas manusia lain yang melihatnya. Efek tersebut mencakup tanggapantanggapan hasil dari pengamatan, pengenalan, imajinasi, baik yang rasional maupun emosional. ${ }^{5}$ Sehingga ketika orang-orang melihat atau mendengar karya seni yang tengah disajikan akan tergerak hatinya dan larut dalam atmosfir di dalam karya tersebut. Efek yang ditimbulkan akan menumbuhkan perasaan senang, sedih, marah dan sebagaainya bergantung dari kepekaan si penikmat seni itu sendiri.

Manusia diberikan kebebasan dalam mengungkapkan makna dan pesan yang akan disampaikan melalui karya yang dihasilkannya. Harapannya apa yang ada dalam

\footnotetext{
${ }^{4}$ Jakob sumarjo, Filsafat Seni. Bandung: ITB Bandung, 2000, 163.

${ }^{5}$ Sudarso Sp., Trilogi Seni Penciptaan Eksistensi dan Kegunaan Seni. Yogyakarta: ISI Yogyakarta, 68.
} 
imajinasi serta pengamatan yang terdapat dalam karya seni dapat dipahami dan dimengerti oleh manusia lain sebagai penikmatnya. Dengan demikian semua karya seni yang dihasilkan manusia mempunyai peran dan fungsi dalam kehidupan masyarakat sebagai pendukungnya.

Dua hal penting dalam membedakan antara pendekatan tradisi dan pendekatan kontemporer khususnya dalam wilayah penciptaan karya musik, bahwa pendekatan tradisi pada hahekatnya mencipta karya seni dengan menggunakan idiom-idiom tradisi seperti: bentuk, teknik (pola), cengkok/wiled dan sebagainya. Idiom ini lebih bersifat memperkaya terhadap repertoar yang telah ada, sedangkan pendekatan kontemporer adalah mencipta karya yang berupaya membebaskan diri dari segala aturan-aturan konvensional yang berlaku pada genre musik, permainan instrumen, dan hal-hal konvensional lainnya, sehingga dalam kelompok ini pencipta diberikan kebebasan dalam mengolah dan menginterpretasikan karya yang akan ia ciptakan tanpa harus terbebani aturan-aturan dalam tradisi. ${ }^{6}$

Mengerjakan sebuah komposisi musik tidak cukup hanya mengandalkan bakat, naluri, insting, spontanitas, dan sebagainya. Proses penyelesaian sebuah komposisi musik dalam bentuk apapun melibatkan begitu banyak pertaruhan akal-budi dan tenaga yang di belakangnya melibatkan berbagai kemampuan trick kecerdasan (intelegensi), kumulasi pengalaman dan pendidikan, kemampuan mengembangkan ide dan wawasan (intelektualitas), ketelitian, dan ketekunan konsentrasi dalam renungan (kontemplasi) di samping tentu saja bakat, naluri, intuisi, spontanitas (kepekaan), dan sebagainya. ${ }^{7}$

\section{Menciptakan Karya Untuk Sebuah Tujuan}

Perjalanan panjang seorang seniman untuk dapat mengungkapkan perasaan yang bergejolak dalam dirinya memerlukan kejernihan dan terangnya hati agar ide atau gagasan dalam menciptakan karya seni tidaklah kering. Perasaan damai dan ketenangan jiwa sangatlah diperlukan dalam hal ini. Mengolah batin dan mengembangkan alam imajinasi untuk dapat menangkap relasi antara alam sekitar dengan perasaan, perlu

\footnotetext{
${ }^{6}$ Waridi,"Memaknai Kekaryaan Karawitan: Dari Sudut Pandang Pendekatan Penciptanya" dalam Selonding Jurnal Masyarakat Etnomusikologi Indonesia Vol.III, No1, Yogyakarta: Jurusan Etnomusikologi ISI Yogyakarta, 2006, 71-75.

7 Suka Harjana, Corat-Coret Musik Kontemporer Dulu dan Kini, Jakarta: Ford Foundation dan Masyarakat Seni Pertunjukan,2003, 72-73.
} 
terus-menerus dilakukan seorang seniman agar supaya perasaan halus yang telah menyatu dalam jiwanya tidaklah kering dan hilang dari dalam dirinya.

Kering atau gersangnya ide untuk mencipta disebabkan sering diumbarnya gagasan tersebut untuk sesegera mungkin dituangkan ke dalam karya. Karena diburu oleh kepentingan-kepentingan sesaat, sehingga seniman sering mengalami kebuntuan yang ujung-ujungnya hanya copy paste dari karya-karya sebelumnya. Bukan berarti yang demikian tidak boleh, hanya saja perlu adanya pengembangan agar tidak wantah atau sama persis dengan karya sebelumnya. Dibutuhkan kecerdasan atau proses kreatif dalam mensikapi dan mengantisipasi kemungkinan apabila hal ini terjadi.

Membuat karya musik tak dapat dilepaskan dari suatu kepentingan tertentu. Untuk kepentingan apa karya musik tersebut diciptakan atau dibuat, apakah untuk iringan tari,teater atau untuk keperluan yang lain. Jika hal ini sudah sangat sering dilakukan, perlu adanya refresh agar terhindar dari kebuntuan. Produktivitas yang tinggi berdampak kwalitas yang rendah. Kwalitas rendah yang ditimbulkan karena seniman yang laris tidak sempat melihat, membandingkan serta merevisi karya-karya terdahulu dengan yang sekarang hingga akhirnya hanya copy paste, tidak membuat pengembangan maupun pembaharuan. ${ }^{8}$

Mempelajari ilmu estetika yaitu suatu ilmu yang mempelajari segala sesuatu yang berkaitan dengan keindahan, mempelajari semua aspek dari apa yang disebut keindahan. Pengalaman yang dapat dirasakan dalam melihat keindahan tak lain dan tak bukan adalah melalui panca indera. Rasa nikmat-indah yang terjadi pada kita, timbul karena peran panca indera yang memiliki kemampuan untuk menangkap rangsangan dari luar dan meneruskannya ke dalam. Rangsangan itu diolah dalam kesan. Kesan ini dilanjutkan lebih jauh ke tempat tertentu di mana perasan kita bisa menikmatinya. Penangkapan kesan dari luar, yang menimbulkan nikmat-indah terjadi melalui dua dari panca indera kita, yakni melalui mata atau telinga. Melalui mata kita sebut dengan kesan visual dan yang melalui telinga kita sebut auditif. ${ }^{9}$ Karya seni yang dapat kita rasakan indah-nikmatnya tersebut merupakan rangkaian dari beberapa unsur yang menyangkut keseluruhan dari sebuah karya.

\footnotetext{
${ }^{8}$ I Wayan Sadra, "Lorong Kecil Menuju Susunan Musik" dalam Waridi, ed., Menimbang Pendekatan Pengkajian dan Penciptaan Musik Nusantara, Surakarta: STSI Surakarta, 2005, 78-79.

${ }^{9}$ A.A.M. Djelantik, Estetika Sebuah Pengantar, Bandung: MSPI, 2004, 2.
} 
Keindahan menurut pandangan Thomas Aquinas harus mencakup tiga kualitas yakni integritas atau kelengkapan, proporsi atau keselarasan yang benar dan kecemerlangan. ${ }^{10}$ Dengan demikian meskipun ada pengorganisasian atau penataan hubungan tertentu dari bagian-bagian yang tersusun tersebut, belumlah menjamin bahwa apa yang terwujud sebagai keseluruhan itu merupakan sesuatu yang indah.

\section{Ide Atau Gagasan Dalam Berkarya Musik}

Gagasan adalah hal yang mendasar atau awal dari suatu proses penciptaan. Dalam diri seorang kreatif, realitas atau kenyataan yang terjadi dalam kehidupan seharihari akan menjadi sumber insprirasi yang memicu kegelisahan. Fenomena-fenomena musikal baik yang berasal dari berbagai ragam musik maupun realitas kehidupan serhari-hari seperti keluarga, lingkungan , fenomena alam, bencana, sosial, budaya, politik adalah segudang bahan yang dapat dijadikan ide atau gagasan seniman dalam menciptakan sebuah karya.

Seniman memiliki cara spesifik dalam berkomunikasi dan mengkomunikasikan gagasan, rasa, serta berbagai fenomena kebudayaan, sosial dan kemanusiaan. Seniman berbicara dan berkomunikasi bukan secara verbal, melainklan lewat rasa dalam bentuk sombol-simbol. Dalam seni musik, seniman berbicara lewat simbol-simbol bunyi, ritme, budaya, sosial dan sebagainya. ${ }^{11}$ Oleh karenanya , ketika seorang seniman mengartikan sebuah kebudayaan masyarakat, mereka tidak sekedar berbicara tentang kebudayaan masyarakat seperti bahasa tutur yang menceritakan sebuah kebudayaan atau sebuah karya tulis yang memaparkan dan menganalisa data yang diperoleh. Bagi seniman pemaparan dan analisa data suatu kebudayaan tidak dituangkan dalam bentuk laporan tertulis seperti halnya kerja penelitian, melainkan dimanfaatkan guna membangun imajinasi untuk kepentingan terwujudnya sebuah karya seni. Dengan demikian proses kelahiran sebuah karya seni yang berangkat dari sebuah kebudayaan tertentu atau sebuah peristiwa historis serta dilakukan secara profesional, memerlukan waktu yang

\footnotetext{
${ }^{10}$ Mudji Sutrisno SJ dan Christ Verhaak SJ., Estetika Filsafat Keindahan, Yogyakarta: Kanisius, 1993, 33.

${ }^{11}$ Waridi, "Mencermati Musik Lagaligo Karya R. Supanggah: Pendekatan, Artikulasi, Instrumentasi, dan Pijakan Repertoar" dalam Y. Sumandiyo Hadi, ed. al. Rinenggaring: Pak Bandem Yang Ngebyar, Yogyakarta: ISI Yogyakarta, 2006, 204.
} 
cukup lama, karena membutuhkan studi literatur, teks, dan konteks kebudayaan masyarakatnya.

Ide atau gagasan dapat juga muncul dengan sendirinya atau karena adanya rangsang awal yang dapat ditemukan oleh si seniman itu sendiri. Menurut Jacquelie Smith rangsang awal adalah sebagai langkah awal di dalam mencipta atau berkarya. Rangsang awal yang dimaksudkan adalah meliputi rangsang dengar (auditif), rangsang penglihatan (visual) rangsang gerak (kinestetik), rangsang peraba dan rangsang gagasan (idesional). ${ }^{12}$ Dengan kepekaan merasakan sesuatu di antara atau di sekeliling kita maka ide atau gagasan dengan sendirinya akan terdorong keluar dari dalam perasaan diri kita.

Rangsang pendengaran terjadi ketika seniman mendengar adanya suara manusia, suara burung dan bunyi-bunyian baik yang berasal dari instrumen musik atau suarasuara lingkungan yang ada di sekitar kita, serta informasi yang dapat mengusik ketenangan hati kemudian diinterpretasikan ke dalam nada-nada secara imitatif kemudian mencurahkannya ke dalam suatu garapan musikal. Rangsang penglihatan dapat pula menjadi sumber inspirasi manakala melihat adanya keganjilan atau sesuatu yang unik dari perilaku manusia, atau alam yang indah. Hal ini dapat di jadikan ide dasar untuk menciptakan karya. Rangsang gagasan terlahir dengan adanya konsep berpikir untuk mengembangkan lebih jauh dari gagasan-gagasan atau ide yang hinggap dalam diri pencipta untuk kemudian dicurahkan ke dalam karya.

Suatu pemahaman dan pandangan bahwa orang lebih menyukai sebuah karya lukis yang beraliran naturalis dari pada ekspresionisme atau orang lebih bisa mengerti terhadap lukisan yang realis dari pada aliran yang abstrak. Sering pula orang tidak dapat memahami atau mengerti dimanakah letak indahnya suatu karya seni baik itu seni rupa, musik, tari atau sebagainya. Pemahaman ini menurut teori subjektif bahwa ciri-ciri yang menciptakan keindahan pada sesuatu benda sesungguhnya tidak ada, yang ada hanyalah tanggapan perasaan dalam diri seseorang yang mengamati sesuatu benda. ${ }^{13}$

Ada beberapa aspek yang menjadikan karya tersebut menjadi indah di antaranya adalah meliputi keutuhan (unity) yaitu bahwa karya yang indah menunjukan dalam keseluruhannya sifat yang utuh, yang tidak ada cacatnya, berarti tidak ada yang

\footnotetext{
${ }^{12}$ Jacquelie Smith, Komposisi Tari, Terjemahan Ben Suharto. Yogyakarta: Ikalasti Yogyakarta, 1985, 2022.

${ }^{13}$ The Liang Gie, Filsafat Keindahan, Yogyakarta: Pusat Belajar Ilmu Berguna, 1997, 50.
} 
berlebihan atau yang kurang. Aspek lain adalah penonjolan atau penekanan (dominance) dimaksudkan yakni mengarahkan perhatian orang yang menikmati suatu karya seni sesuatu hal tertentu, yang dipandang lebih penting dari pada hal-hal yang lain. Adanya sifat kontras dalam penyusunannya. Aspek berikutnya adalah adanya keseimbangan (balance) adalah sifat manusia bahwa dalam menempatkan dirinya terhadap lingkungan hidupnya sendiri menghendaki adanya keseimbangan. Terbentuknya kebudayaan dan perkembangan ilmu pengetahuan dan teknologi, keseimbangan tetap merupakan syarat estetik yang mendasar dalam semua karya seni. ${ }^{14}$ Dengan demikian bahwa karya seni yang indah-nikmat, hal-hal yang menjadi dasar dari aspek estetik harus ada dalam karya tersebut yakni keutuhan atau kebersatuan, penonjolan atau penekanan, serta adanya keseimbangan.

\section{Kerangka Konseptual dalam Karya}

Berbicara tentang esensi dari kerangka konseptual dalam berkarya apabila kita analogkan dengan konsep kerangka dalam membangunan rumah, maka perlu adanya persiapan secara matang tentang apa saja yang harus dipersiapkan agar bentuk dari bangunan rumah tersebut terwujud seperti apa yang menjadi harapanya. Secara otomatis kita mempersiapkan bahan-bahan yang akan dipakai agar rumah tersebut terbentuk, seperti mempersiapkan pondasi rumah agar kuat, batu, kayu semen pasir dan sebagainya. Kemudian bangunan rumah itu juga harus sesuai dengan gambar yang telah dibuat. Begitu pula halnya ketika kita membicarakan tentang kerangka konseptual dalam berkarya sudah barang tentu materi pertama yang dibicarakan adalah tentang ornamen apa saja agar karya itu terwujud. Pemilihan bahan berupa konsep-konsep yang melatar belakangi karya haruslah jelas dan terarah. Seperti misalnya membicarakan karya seni berupa lukisan, dengan sendirinya kita mempersiapkan konsep yang jelas tentang lukisan dengan aliran yang mendasarinya. Kemudian selanjutnya mempersiapkan materi atau bahan mentahnya seperti cat, kanfas, model atau ide tentang apa yang mau digunakan atau sumber insprirasinya dari mana. Setelah itu kita menentukan atau mencari kerangka teori yaitu landasan yang dapat dipakai untuk memperkuat dan mempertajam karya kita dengan dasar teoritis, agar supaya apa yang menjadi dasar karya itu dapat dipertanggungjawabkan secara teori pula. Demikian

\footnotetext{
${ }^{14}$ A.A.M. Djelantik, 37- 46.
} 
seterusnya sama halnya yang terjadi dengan disiplin ilmu yang berbeda, seperti dalam disiplin tari, musik, teater atau disiplin ilmu lainnya.

Sebuah karya seni akan dapat tercipta manakala mempunyai konsep dalam penggarapan yang matang dan jelas. Dengan adanya kejelasan dan kematangan dalam mempersiapkan karya yang akan diciptakan, dengan sendirinya bobot atau nilai yang terkandung di dalamnya yaitu pesan dan makna akan dapat dimengerti oleh masyarakat sebagai pemerhati sekaligus penikmatnya. Oleh karena itu, perlu adanya persiapkan secara matang dan menyeluruh mengenai segala aspek yang menyangkut tentang lahirnya sebuah karya. Beragam jenis dan bentuk karya seni dalam menghadirkan dirinya, maka akan terjadi pula beragam bahasa ungkap dengan beragam karakteristiknya yang digunakan beserta idiom estetis yang melengkapi kosa tema dengan makna masing-masing dalam kontek estetis yang digunakan dalam proses tersebut. Sehingga tidak semua karya seni dapat dimengerti dan dibaca oleh semua kalangan, terutama bagi penikmat yang hanya biasa menikmati satu sajian dan terbatas pada pemahaman terkait dengan disiplin ilmu yang biasa ia jumpai. Adanya pemahaman seperti itu karena kurangnya wawasan atau pandangan seorang seniman. Tidak ada salahnya apabila seorang seniman mulai sekarang harus membuka cakrawala pandangan yang luas dan baru agar tidak tidak terjadi stagnan. Pem belajaran itu penting guna mempersiapkan secara matang tentang kerangka konsep yang akan dipakai untuk melahirkan karya baru ciptaanya.

Ketika kita membicarakan kerangka konsep terkait dengan karya seni, maka perlu adanya kesadaran seniman dalam memahami tentang apa saja yang akan dipakai dalam karya itu, di dalamnya terkait tentang konsep yang jelas, mau diapakan dengan hasil karya itu, bahan apa saja yang harus disediakan, sehingga tidak terkesan asal jadi namun didasari pemikiran yang matang hingga karya itu terwujud. Sebagai contoh apabila kita mau menuangkan ide atau gagasan karya ke dalam bentuk musik, maka yang perlu dipersiapkan sebagai acuan atau dasar konsepnya adalah bagaimana konsep garap atau penyajian musiknya, apakah sendiri atau berkelompok, unsur bunyi apa yang harus dimunculkan, hal ini berkaitan dengan instrumen apa saja yang dipakai, berapa jumlah pemain yang dibutuhkan dan bagaimana dengan kostumnya. Semua ini dimaksudkan agar konsep yang telah dibingkai tidak keluar dari apa yang diharapkan si pencipta, yaitu maksud dan tujuannya terbaca oleh penikmatnya dan dapat 
mempertanggungjawabkan atas karyanya. Memang tidak mudah seperti apa yang kita bayangkan, akan tetapi bila konsep dasarnya sudah jelas, maka akan membantu diri seniman dalam menuangkan ide atau gagasan karya tersebut secara maksimal.

Seorang seniman kadangkala enggan untuk membicarakan kerangka konsep lebih-lebih kerangka teori. Menurutnya konsep itu terkadang menggelinding bagai gulungan salju yang terus menggelinding dan berputar tanpa tahu kapan ujung pangkalnya. Tinggal bagaimana sikap kita menghadapi satu permasalahan tersebut, apakah kita akan membiarkan konsep tersebut mengembara dalam angan dan imajinasi, ataukah ada batasan yaitu konsep yang jelas, sehingga ada batas-batas tertentu yang membatasi alam ide atau gagasan itu ke dalam sebuah karya dengan batasan dan konsep yang matang. Kesemuanya adalah pilihan, karena setiap seniman masingmasing mempunyai perbedaan dalam cara pandang dan mensikapi baik rasa tanggung jawab secara individu maupun kepada masyarakat sebagai penikmat sekaligus yang memberikan penilaian. Hal itulah yang membedakan seniman satu dengan seniman lainnya. Begitu pula halnya ketika seniman berbicara mengenai karya-karyanya kadangkala ia menyampaikan dengan kata-kata akan tetapi kandungan makna yang bisa dimunculkan adalah lewat simbol-simbol.

Uraian tersebut di atas apabila kita hubungkan dengan konsep karya yang terkait dengan fenomena sosial, maka hal-hal lain perlu adanya perhatian khusus seperti apa yang terjadi dengan fenomena sosial tersebut. Bagaimana seorang seniman menangkap fenomena itu terkait dengan karya yang akan dibuat, apa yang menjadi dasar hingga karya itu terwujud, bagaimana dasar teorinya dan masih banyak lagi kiranya yang perlu dipertajam sehingga karya itu benar-benar memiliki makna yang dalam. Seorang seniman dapat mendayagunakan alam dengan merekayasa dan mereka bentuk secara estetis hal-hal apa yang ada di alam dan sekelilingnya untuk dijadikan sebuah karya seni.

Alam imajinasi dan bayang-bayang yang terus dikembangkan lewat penginderaan baik yang telah dialami maupun tidak, menjadikan dasar untuk menuangkan imaji itu ke dalam realita dan menuangkannya ke dalam karya. Seniman seakan berjalan dalam lautan imajinasi yang luas membentang dan penuh dengan gelombang makna yang ada di dalamnya. Terkadang makna yang tersirat tak mampu terbaca oleh kita, bahkan menganggap seperti di luar nalar dan jangkauan daya pikir 
kita. Pengembaraan alam imajinasi serta kepekaan seniman dalam menangkap fenomena alam dan lingkungan sekitarnya, menjadikan segudang makna atau ide gagasan yang dapat dituangkan ke dalam karya.

\section{Proses Kreativitas Dalam Karya Musik}

Tanpa kreativitas seorang seniman tidak akan mampu menangkap keindahan alam. Merekamnya kembali lewat daya imajinasi dan mencurahkan perasaan itu lewat karya seninya. Seorang pencipta dengan proses kreatifnya meliputi suatu tangkapan data inderawi, perasaan tentang apa yang dirasakan, eksplorasi pengamatan-pengamatan dan perasaan-perasaan, hubungan imajinatif dari pengalaman sekarang dengan pengalamanpengalaman yang tersimpan, akhirnya pembentukan suatu produk baru.

Kreativitas di dalamnya menyangkut pemikiran yang bersifat imajinatif. Artinya hal-hal yang ada dalam alam imajinatif dikembangkan dan dibentuk berdasar atas apa yang ada dalam angan-angan tersebut, kemudian ditungkan di dalam karyanya. Pengembaraan alam imajinatif tanpa sentuhan tangan seniman tidak akan berarti atau bahkan hilang manakala tidak ditindak lanjuti dengan menuangkannya dalam bentuk karya. Sering tidak kita sadari bahwa suara kendaraan bermotor, suara mesin gergaji, suara burung, suara-suara yang bersumber dari lingkungan sekitar merupakan sumber bunyi yang dapat dijadikan sebagai bahan atau sumber inspirasi dalam melahirkan karya seni. Sumber-sumber bunyi tersebut di tangan kreator dapat dijadikan sebagai elemen dalam musik yakni dengan cara merespon dan mensikapinya sebagai sumber dan dikaji serta dimaknai dalam jangkauan wilayah musik, kemudian diolah menjadi bagianbagian atau unsur-unsur di dalam musik yaitu ritme, melodi, harmoni.

Melalui musik kita akan dapat merasakan serta merespon indahnya alam semesta dengan nada-nada dan ritme-ritme yang coba kita susun berdasar atas keindahan alam tersebut dari kemampuan kita dalam menginterpretasikannya. Imanuel khant berpendapat bahwa musik sebagai hasil karya manusia merupakan bahasa eskspresi yang masih harus diterjemahkan. Sehingga tidak cukup diterangkan hanya 
melalui emosi. ${ }^{15}$ Musik merupakan rekayasa yang sepenuhnya terbentuk karena kesengajaan. Bukan karena factor kebetulan walaupun factor itu sedikit banyak sering juga berpengaruh. ${ }^{16}$ Sehingga diperlukan kreator yang mumpuni dalam menciptakan karya musik.

Musik sebagai karya seni dapat digambarkan sebagai ekspresi perasaan dalam diri manusia yang dirubah oleh imajinasi dan diberi bentuk melaui rangkaian bunyi. Unsur bunyi adalah hal terpenting di dalam musik, karena menurut pemahaman penulis, kita tidak akan dapat merasakan musik itu indah atau tidak, gaduh atau lembut karena unsur bunyi yang kita dengarkan. Kita dapat memejamkan mata tanpa harus melihat, hanya pendengaran dan perasaanlah yang dapat menangkap dan merasakan unsur bunyi yang dipadukan dengan pola rime dari musik itu. Kalau kita melihat dan memahami dari segala aspek yang berbeda, mencoba menghubungkan dengan disiplin seni yang berbeda, aspek kreativitas memang hal yang sangat vital. Tanpa kreativitas seorang seniman lukis misalnya, tidak akan mampu menangkap keindahan alam, kemudian merekamnya kembali lewat daya imajinasi dan mencurahkan perasaan itu lewat karya lukisnya.

Seorang pencipta dengan proses kreatifnya meliputi suatu tangkapan data inderawi, perasaan tentang apa yang dirasakan, eksplorasi pengamatan-pengamatan dan perasaan-perasaan, hubungan imajinatif dari pengalaman sekarang dengan pengalamanpengalaman yang tersimpan. Memahami proses kreatif, terutama hal yang berkaitan dengan pengalaman pribadi ketika melihat, mendengar dan merasakan tentang hal-hal unik dari fenomena baik politik,alam atau sebagainya, kemudian memikirkan dan mengimajinasikan ke dalam gagasan atau ide untuk dapat menuangkannya menjadi sesuatu karya baru.

Aktivitas mengolah suara baik suara vokal melalui nada-nada tinggi-rendah, kuat-lemah, panjang-pendek, timbre (warna nada), ataupun mengolah instrument dengan beragam bentuk dan nadanya, bahkan menambahkan alat-alat lain atau menggabungkan kesemuanya adalah hal biasa yang dilakukan oleh seorang kreator .

\footnotetext{
${ }^{15}$ Sukatmi Susantina, Nada-Nada Radikal Perbincangan Para Filsuf Tentang Musik, Yogyakarta: Panta Rhei Book, 2004, 40-41.

${ }^{16}$ Suka Harjana, 3 .
} 
Semakin besar dan komplek karya seni semakin rumit dan semakin berat pula proses penyelesaiannya. Harus pula bahwa ukuran besar dan kompleknya sebuah karya seni tidak terletak pada ukuran matra, durasi dan berbelitnya sebuah komposisi. Komposisi yang pendek bisa jadi lebih menarik dari pada yang panjang tapi terkesan monoton dan membosankan. Hal ini kepekaan, kepiawaian dan pengalaman panjang seorang pencipta untuk mengolah dan meracik dalam proses kreativitasnya menuju sebuah komposisi.

Cara-cara yang ditempuh dalam membuat komposisi tentunya tak lepas dari pemahaman mengenai elemen-elemen dasar musik yang akan diciptakan. Adapun elemen dasar musik itu sendiri meliputi : ritme, melodi, harmoni, dinamika, tempo, timbre, dan bentuk. Hal itu pula yang harus diperhatikan ketika mau menciptakan karya musik, kesemua elemen dasar tersebut tak bisa dihindarkan, karena masing-masing mempunyai peranan dalam menopang suasana.

Proses kreativitas dapat pula dilakukan dengan menambahkan alat instrument yang mungkin tidak lazim seperti perkakas dapur, botol-botol minuman, pralon, mesin gergaji, suara kendaraan bermotor dan lain-lain. Kesemuannya itu merupakan pernakpernik yang dapat dijadikan sebagai ornamentasi dalam proses penggarapan. Hal ini dimungkinkan apabila suasana yang diharapkan memang membutuhkan alat-alat tersebut, atau apabila kegelisahan pencipta yang tidak mau terbelenggu dalam bentukbentuk konvensional. Alam pikiran dalam kontemplasi atau perenungan membebaskan diri dari ruang yang sudah mapan untuk mencari bunyi-bunyi liar sebagai sumber inspirasinya.

Bunyi atau suara sebagai asal muasal musik benar-benar menjadi energi-energi liar yang belum menemukan arti. Ditangan seniman bunyi atau suara tersebut diproses menjadi rangkaian nada-nada, sebagai perwakilan ungkapan hati atau ekspresi dalam diri seniman itu sendiri, sehingga nada-nada tersebut memiliki arti yang sebenarnya.

Ketepatan dalam memilih pemain juga tak bisa dilewatkan sebagai pelaksana dalam proses kreativitas, karena kesalahan dalam memilih pemain akan berdampak tidak sampainya gagasan ide dalam proses kekaryaan tersebut. Ada banyak cara dalam proses kreativitas ini, hanya saja keterbatasan penulis dalam memahaminya masih perlu diasah dan belajar lebih mendalam, termasuk di dalamnya sendi-sendi apa saja yang bisa diproses dalam menuangkan ide ke dalam karya. 
Setiap bentuk karya seni ditangkap dengan berbagai cara oleh perasaan kita, kemudian masing-masing tumbuh dari sebuah kebutuhan yang sama, untuk memberi substansi ekspresi terhadap perasaan-perasaan, gagasan-gagasan, wawasan-wawasan dan pengalaman-pengalaman. Selanjutnya orang mulai mencari dan membicarakan tentang bagaimana cara membentuk karya seni menjadi wujud yang dapat dilihat atau didengar. Seorang seniman melalui pengalaman estetisnya dan ide-ide yang ada dalam benaknya mencoba mengungkapkan ide-ide atau gagasannya itu ke dalam karya yang ingin ia ciptakan. Banyak di antara pencipta seni dalam menciptakan sebuah karya seni dengan beragam metode yang berbeda dari satu dengan lainnya.

Tingkat kepekaan, pengalaman dalam berkesenian memberikan warna yang berbeda dalam setiap karyanya. Kreativitas seseorang tidaklah sama, tergantung dari kebiasaan mengkreasi dan mengembangkan pengalaman serta mengimajinasi segala hal yang berkaitan dengan sumber inspirasinya untuk dapat menciptakan sebuah karya. Pengalaman-pengalaman yang ada pada dirinya memberikan kesempatan bagi aktivitas untuk mengembangkan kreativitas dalam menciptakan sebuah karya.

Pengembangan kreativitas pada dasarnya, dapat diklasifikasikan menjadi tiga bagian utama yaitu eksplorasi, improvisasi dan komposisi. ${ }^{17}$

\section{Eksplorasi Dalam Karya Musik}

Melalui ekplorasi ini kita akan dapat mengembangkan atau menentukan tema yang akan diciptakan melalui ceritera-ceritera, ide-ide dan konsep yang ada. Kemudian berpikir, berimajinasi, merasakan, menanggapi dan menafsirkan tentang tema yang dipilih. $^{18}$

Begitu seterusnya sehingga kita tidak menyadari betapa luasnya pemahaman dan daya khayal kita menuju ke dalam ruang yang sebelumnya belum kita kenal. Keberanian dalam mengungkapkan perasaan, kepenatan yang seolah-olah membelenggu dan menutup daya kekuatan imajinasi, kepekaan kita terhadap musik-

\footnotetext{
${ }^{17}$ I Wayan Senen, Wayan Beratha Pembaharu Gamelan Kebyar Bali, Yogyakarta: Tarawang Press, 2002, 95.

${ }^{18}$ I Made Bandem, “ Metodologi Penciptaan Seni “, buku ajar Program Pasca Sarjana ISI Yogyakarta, 2001,6 .
} 
musik yang telah akrab ditelinga kita akan membantu serta membuka cakrawala berpikir dalam menuangkanke ide ke dalam sebuah karya.

Ide-ide tersebut tidak akan pernah muncul manakala kita tidak berusaha menciptakan atau menggalinya. Salah satu cara adalah dengan melakukan eksplorasi yaitu sebuah percobaan untuk mengakumulasi dan mengakomodasi keleluasaan dari kemungkinan untuk berkarya berdasarkan keleluasaan pilihan dengan variabel yang digunakan.

Setiap manusia mempunyai tingkat pemahaman dan daya khayal yang berbeda tergantung dari pemahaman yang dimiliki. Tingkat ketajaman tergantung pada latar belakang dan proses kreatif yang melatarbelakanginya. Sehingga tidak akan sama antara manusia yang satu dengan manusia lainnya dalam mencapai proses kreativnya.

Dalam kesempatan ini penulis mencoba mengekplorasi pertama dengan sebuah karya yang telah ada yaitu lagu bernuansa langgam Jawa dengan judul ela-elo. Mencari hal-hal baru untuk dapat dikembangkan melalui jalinan nada maupun liriknya yang telah ada, kemudian mencoba mengeksplor nada-nada maupun liriknya berdasarkan pada keleluasaan pilihan dan variabel yang penulis gunakan.

Kedua dengan mencoba mengekplorasi instrumen apa saja yang sesuai dengan karakter dari lagu itu. Dengan demikian untuk menemukan instrumen yang sesuai diperlukan beberapa kali eksplorasi terhadap beberapa instrumen pilihan. Salah satunya yang pernah penulis coba adalah dengan instrument bonang. Ternyata setelah beberapa kali dilakukan eksplorasi, bunyinya tak seimbang dengan karakter vokal yang dihasilkan. Akhirnya penulis mencoba mencari karakter yang sesuai dan dipilihlah instrument berupa gender barung, gender penerus, slenthem, gambang, rebab, kendang, kendang bem, rebana. Kesemua instrument tersebut melalui uji eksplorasi.

\section{Improvisasi Dalam Karya Musik}

Improvisasi memberikan kesempatan yang lebih besar bagi imajinasi, seleksi, dan mencipta dari pada tahap eksplorasi. Karena tahap improvisasi terdapat kebebasan yang lebih, sehingga jumlah keterlibatan diri dapat ditinggalkan. Kreativitas melalui 
improvisasi kadang-kadang diartikan sebagi "terbang ke yang tak diketahui“. ${ }^{19}$ Inilah saatnya seorang pencipta mempergunakan simpanan imaji-imaji dan melahirkan dalam bentuk yang baru. Melalui improvisasi seseorang diberikan kebebasan dalam mengolah maupun menentukan ekspresi di dalam permainannya.

Melepaskan ikatan yang membelenggu untuk bebas bergerak, merentangkan gagasan yang ada dalam idenya untuk mengepakkan sayap berkelana atas kemauan idenya, mengembangkan pikirannya untuk menuju alam bebas tidak terikat dalam satu ikatan. Improvisasi juga dimaksudkan sebagai percobaan-percobaan, membedakan, mepertimbangkan, membuat harmonisasi, dan menemukan integritas dan kesatuan terhadap berbagai percobaan yang telah dilakukan. ${ }^{20}$

\section{Pembentukan atau Komposisi}

Hasil dari perjalanan tentang proses adanya ekplorasi maupun improvisasi atau melakukan hal-hal yang sifatnya kreativitas dari seseorang, adalah dengan membentuk apa yang telah dilakukan selama ini. Merasakan, menghayalkan dengan ide-ide atau gagasan tanpa adanya suatu pembentukan atau komposisi yang diciptakan, maka hanya akan ada dalam angan-angan. Semua yang dilakukan oleh seorang seniman belumlah berarti apabila karya yang menjadi hasrat atau ungkapan tersebut belum berbentuk.

Kebutuhan membuat komposisi tumbuh dari hasrat manusia untuk memberi bentuk terhadap sesuatu yang ia temukan. ${ }^{21}$ Pekerjaan membuat karya atau komposisi membutuhkan kontrol maupun dorongan imajinatif di samping kesabaran dan kerja keras. Seorang pencipta atau kreator dalam mengembangkan kreativitasnya tidak dapat dengan tergesa-gesa, atau diperintah untuk secepat mungkin menyelesaikan apa yang diperintahkan. Mereka diberikan keleluasaan dan kebebasan dalam mengembangkan apa yang ada di pikiran mereka. Biarkan seorang pencipta melalui daya kreatifnya diberikan kebebasan untuk dapat melahirkan karya sesuai kehendak hatinya.

Manusia mempunyai kapasitas yang unik untuk berpikir dan bertindak secara kreatif, suatu kemampuan yang memungkinkan pencapaian untuk hal-hal yang tak

\footnotetext{
${ }^{19}$ Alma M Hawkins, Mencipta Lewat Tari, terjemahan Y. Sumandiyo Hadi, Yogyakarta: Manthili Yogyakarta,1990, 29.

${ }^{20}$ I Made Bandem, 6.

${ }^{21}$ Alma M Hawkins, 41.
} 
dikenal sebelumnya. Ada beberapa bukti bahwa seseorang yang sangat kreatif memiliki ciri-ciri tertentu seperti keterbukaan terhadap pengalaman-pengalaman baru. kecakapan mengurai, sensitivitas estetis, imajinasi, kekuatan kreatif yang sangat luas. ${ }^{22}$

Pembentukan atau komposisi pada dasarnya hasil dari proses perjalanan waktu seseorang untuk dapat menciptakan sebuah karya melalui beragam cara baik itu eksplorasi, improvisasi atau cara-cara lain untuk digabungkan menjadi satu kesatuan bentuk.

\section{Penutup}

Tumbuh dan berkembangnya tingkat kreatif seseorang dapat pula dipengaruhi oleh lingkungan yang mendukungnya. Pencipta diberikan kebebasan untuk merespon dengan caranya sendiri tanpa harus mendapat tekanan dari mana pun. Faktor-faktor keamanan dan kenyamanan serta kebebasan psikologis, bersama-sama dengan pengertian simpatik dari kemudahan seseorang, kelihatannya sangat penting mempengaruhi kemajuan dan kreativitas seseorang. Ketika dalam pikiran maupun suasana tidak nyaman baik itu lingkungan maupun psikologis maka segala sesuatu yang dikerjakan menjadi tidak maksimal. Artinya keadaan nyaman dengan suasana hati yang tentram akan dapat menciptakan karya dengan bobot dan nilai secara optimal. Sehingga tidaklah mengherankan jika seorang seniman harus mencari tempat yang sunyi bahkan menyendiri, hal itu ia lakukan semata-mata untuk dapat merenung dan mengembangkan alam imajinasi, ke dalam ide atau gagasan untuk dapat mencurahkan semua yang ada ke dalam karya yang ia ciptakan.

Setiap pribadi manusia diberikan beragam kemampuan oleh Tuhan. Oleh karena perbedaan itulah maka cara yang ditempuh dalam mengolah, meracik, memahami keindahan di dalam sebuah karya seni berbeda dari pribadi satu dengan pribadi lainnya. Begitu pula setiap pribadi manusia tidak akan sama dalam melihat keindahan di dalam sebuah karya seni. Hati yang sedih dan gembira akan berbeda dalam memandang atau mendengar keindahan dalam sebuah karya seni.

Batin yang dirundung kesedihan tidak akan dapat menangkap keindahan lirik lagu yang didendangkan, begitu pula kemarahan dalam hati tidak akan terobati oleh suasana alam yang indah. Dengan demikian keindahan akan dapat dimengerti dan

${ }^{22}$ Alma M Hawkins, 43. 
dipahami oleh seseorang dalam kondisi bahagia, karna dalam pikiran dan jiwa yang bahagia memungkinkan seseorang dapat menerima dan memahami akan keindahan.

Kebahagiaan hati memungkinkan seseorang dengan mudah dapat menciptakan sebuah karya seni, karena jauh dari rasa gundah dan gelisah, serta tidak terbebani oleh pikiran-pikiran yang bersifat membelenggu aturan- aturan yang mengekang akan kebebasan dalam berkarya. Hal yang terpenting adalah tidak menanggalkan etika dan estetika di dalam karya yang diciptakannya.

\section{Kepustakaan}

Bahari, Nooryan, 2008, Kritik Seni Wacana Apresiasi dan Kreasi, Yogyakarta: Pustaka Pelajar.

Bandem, I Made, 2001, “ Metodologi Penciptaan Seni “, buku ajar Program Pasca Sarjana ISI Yogyakarta.

Djelantik, A.A.M, 2004, Estetika Sebuah Pengantar, Bandung: MSPI.

Hawkins, Alma M, 1990, Mencipta Lewat Tari, Dialihbahasan ke Bahasa Indobesia oleh Y. Sumadiyo Hadi. Yogyakarta: Manthili Yogyakarta.

Hawkins, Alma M., 1991, Bergerak Menurut Kata Hati, diterjemahkan oleh : I Wayan Dibia, 2003, Jakarta: Ford Foundation dan MSPI.

Liang Gie, The, 1997, Filsafat Keindahan, Yogyakarta: Pusat Belajar Ilmu Berguna

Senen, I Wayan, 2002, Wayan Beratha Pembaharu Gamelan Kebyar Bali Yogyakarta: Tarawang Press

Smith, Jacquelie, 1985, Komposisi Tari, Terjemahan Ben Suharto. Yogyakarta: Ikalasti Yogyakarta

Soedarso, Sp., 2006, Trilogi Seni Penciptaan Eksistensi Dan Kegunaan, Yogyakarta: Penerbit ISI Yogyakarta.

Soedjono, Soeprapto, 2006, “ Dialektika Seni: Proses Komunikasi "Informasi dan Tanggapan” Estetis" dalam Y. Sumandiyo Hadi, et al., ed., Rinengganing : Pak Bandem Yang Ngebyar.

Sumardjo, Jakob, 2000, Filsafat Seni, Bandung: ITB.

Susantina, Sukatmi, 2004,Nada-Nada Radikal Perbincangan Para Filsuf Tentang Musik,Yogyakarta: Panta Rhei Book 
Waridi, 2006, "Mencermati Musik Lagaligo Karya R. Supanggah: Pendekatan, Artikulasi, Instrumentasi, dan Pijakan Repertoar" dalam Y. Sumandiyo Hadi et al., ed., Rinenggaring: Pak Bandem Yang Ngebyar, Yogyakarta: Penerbit ISI Yogyakarta.

2006,"Memaknai Kekaryaan Karawitan:Dari Sudut Pandang Pendekatan Penciptanya" dalam Selonding Jurnal Masyarakat Etnomusikologi Indonesia Vol.III, No1 Yogyakarta: Jurusan Etnomusikologi ISI Yogyakarta

Djelantik, A.A.M., 2004 Estetika Sebuah Pengantar ,Bandung: MSPI

Sutrisno, Mudji SJ dan Verhaak, Christ SJ.,1993, Estetika Filsafat Keindahan,Yogyakarta:Kanisius

Harjana, Suka, 2003, Corat-Coret Musik Kontemporer Dulu dan Kini, Jakarta: Ford Foundation dan Masyarakat Seni Pertunjukan,

Sadra, I Wayan, 2005, "Lorong Kecil Menuju Susunan Musik" dalam Waridi, ed., Menimbang Pendekatan Pengkajian dan Penciptaan Musik Nusantara Surakarta: STSI Surakarta 